\title{
DEVELOPMENT DIRECTIONS AND OPPORTUNITIES OF MARKET PLACES IN THE BALATON REGION ESPECIALLY CONCERNING LOCAL PRODUCERS' MARKETS
}

\author{
Csilla Nezdei ${ }^{1}$, Zoltán Horváth ${ }^{2}$
}

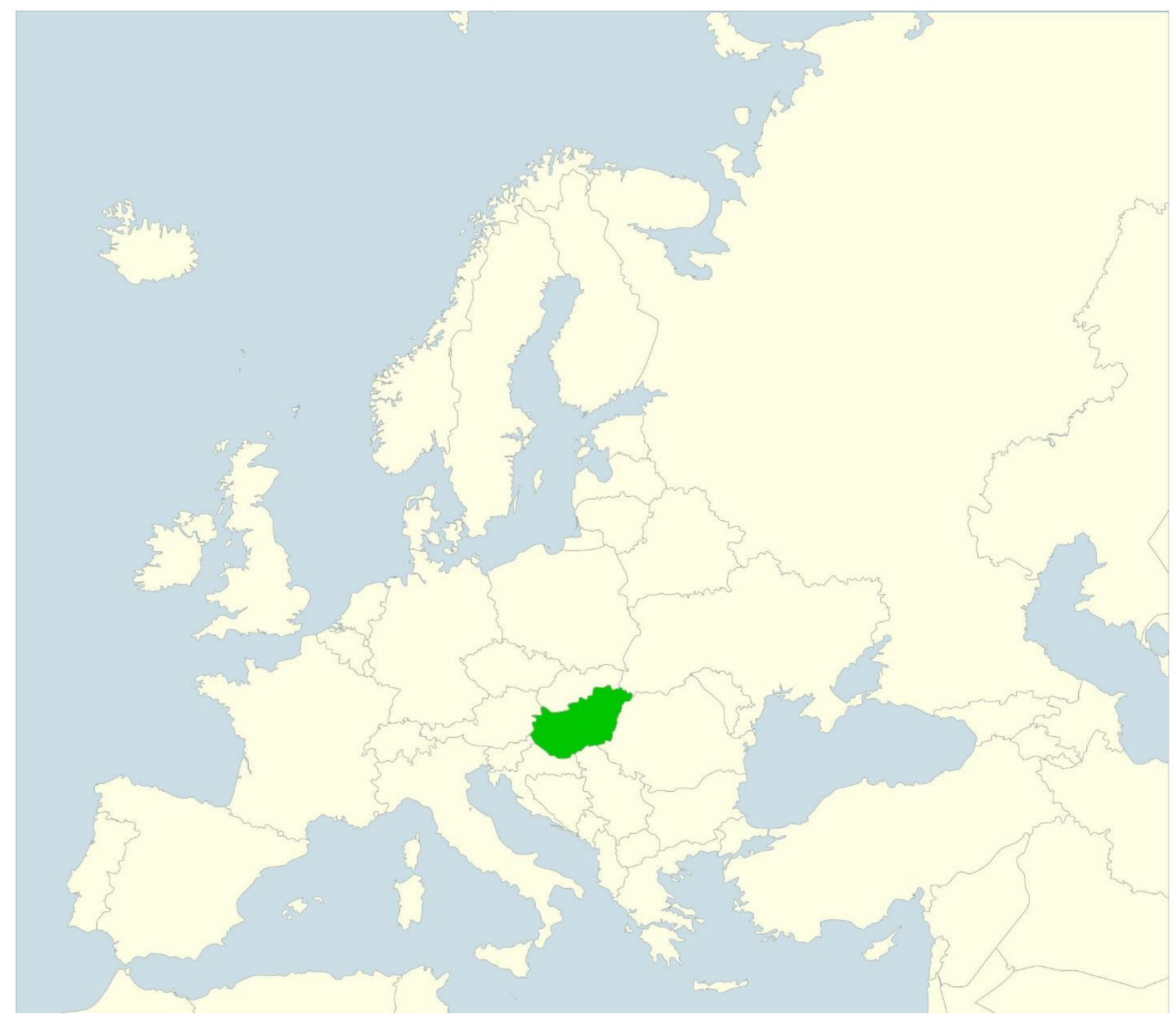

${ }^{1}$ Csilla Nezdei; (Ph.D. candidate) University of Pécs, Faculty of Sciences, Doctoral School of Earth Sciences; Ifjúság útja 6., H-7624 Pécs, Hungary, n.csyllu@hotmail.com, nezdei.csilla@gmail.com; ORCID: 0000-0001-6742-1211

2 Zoltán Horváth; (Ph.D. candidate) University of Pécs, Faculty of Sciences, Doctoral School of Earth Sciences; Ifjúság útja 6., H-7624 Pécs, Hungary; hozool@gmail.com; ORCID: 0000-0002-5809-8923 


\begin{abstract}
Nowadays, the change of travel and consumption habits of tourists brings a destination into prominence. The characteristic products of the destinations with complex tourism supply appear as univocal association of ideas for the potential tourists. In the analysed Balaton region, besides the accentuated waterside tourism, the definite development of the gastronomy trends can be seen in the certain supply channels. The aim of our research was to determine the development opportunities of the market places and their place in the consumers' preferences, promising interesting results in relation to the consumer standards of the Hungarian and international demand. We detected three major directions in our researches: the linking of the place with a product, the market as a programme and rural development-gastronomy directions. The present study aims to reveal the rural development direction: the market place forms a space to the sales of the quality, locally produced foodstuff motivating more and more people to create a more near-natural lifestyle.
\end{abstract}

Keywords: local product, rural development, tourism

\begin{abstract}
Absztakt: Napjainkban a turisták utazási és fogyasztási szokásainak változása az attrakciók, termékek helyett a desztinációkat helyezi előtérbe. A komplex turisztikai kínálattal rendelkező fogadóterületek jellegadó terméke(i) a potenciális turisták fejében egyértelmü képzettársításokként jelennek meg. A tanulmányban vizsgált Balatontérségben a hangsúlyos vízparti turizmus mellett a gasztronómiai trendek határozott fejlődése mutatkozik meg az egyes értékesítési csatornákon, így a termelői piacokon is. Kutatásunk célja volt meghatározni a piachelyek fejlesztési lehetőségeit fogyasztói preferenciákban elfoglalt helyét, amely az üdülőkörzetben megjelenő magyar és nemzetközi fogyasztói kívánalmak függvényében érdekes eredményeket ígért. A piachelyek turisztikai attrakcióvá válásának lehetőségeit vizsgálva, kutatásunk során három fejlesztési irányt azonosítottunk: a hely termékkel való összekapcsolása, a piac mint program és a vidékfejlesztés - gasztronómia irányzatokat. Jelen tanulmány a vidékfejlesztési irányt hivatott feltárni: a piachely teret formál a minőségi, lokálisan megtermelt élelmiszerek értékesítésének, amellyel egyre több embert motivál egy természetközelibb életstílus megteremtésére.
\end{abstract}

Kulcsszavak: helyi termék, vidékfejlesztés, turizmus

\title{
1. Introduction
}

\subsection{The geographic role of the Balaton region}

Today, numerous leisure activities are available to tourists. In a Central-European context and in Hungary as well, the Balaton region can be classified among the most important tourism destinations (Hungarian Tourism Agency (2017). Its reputation was strengthened by the travel habits and opportunities of the socialist era to which many European tourists still think with nostalgia. After the change of the regime in Hungary, the economic structure changed significantly leading to the deepening of spatial differences. However, the regulations of the Balaton Accentuated Tourism Zone (BATZ) were formed according to the preservation of the landscape values, on the waterside and puffer settlements the strict regulations are prevailing alike. The coherent chain of the settlements of the Balaton region profits from the more and more innovative products but in the puffer zones, we can detect the signs of recession more and more, both concerning population loss, ageing and outmigration. The direct and indirect interventions of the last decades did not moderate the social polarisation in the puffer zone raising difficulties on the adaptation of the innovative technologies as well. The pulling up of these processes and the raising of the quality of life makes it necessary to form new or novel opportunities (KwiecinskaZdrenka, 2013). The landscape features of the villages 5-10 km from the waterside favour agriculture so its utilisation could be a plausible solution. The local producer markets established 
in 2011 in Hungary provided an indirect opportunity for this rural area to utilise the local endowments where besides the local population, the potential market outlet could be assured by tourism. The local markets extend at the same time as the range of possible foodstuff purchasing locations and the leisure activity supply, so in the analysed tourism area, the understanding and analysis of the theoretical framework of the local producers' markets promised interesting results. The market place development as a tool for indirect spatial development fits the strategic objectives of the campaigns entitled "Put a product of Balaton to the table", "Natural Balaton! Healthy environment, clean Balaton!", "Health and rejuvenation in Balaton!" and "Innovative Balaton!" (BIKN Kft 2017).

In the bottom-up process of rural development, besides the cooperation of the locals (local population, civilian organisations, local government, locally active enterprises) of the village, angling, gastro and cycling tourism offer such alternatives which can effectively serve the improvement of the quality of life of the rural population both one by one or as a tourism package by hosting tourists and providing services (Piskóti, et al. 2002; Reisinger, 2010; Hjalager, et al. 2018). Getting to know the supply of gastronomy, the local, traditional tastes is ensured for the inquiring ones through different channels, such as the so-called village guest table service or selling in local producers' markets. The crowd of the markets enchanted the visitors for centuries with their wide or unique product supply, with the possibility to bargain or with the meetings and friendly interactions (Andrásfalvy, B. 2006; Domonkos O. 1991) preserving their unique recreational role. Getting an inside view of the everyday life of the rural people, getting to know different folk occupations, the preservation of the rural tastes and folk traditions represent an attraction for the rural and urban population, that is why surveying this topic can be challenging on the Central-European level (Berki and Csapó, 2008, Fehér, and Kóródi, 2008; Gonda, 2013; Szabó, 2013; Trunfio et al. 2006; Tew and Barbieri, 2012).

\subsection{The regional importance of market places}

Nevertheless, in the Western European countries and in overseas, similar market initiations have been functioning successfully for decades (Renting et al. 2003; Spilková et al. 2013; Syrovátková, 2016) In Hungary, this good practice was adapted only in the last couple of year. The favourable social-environmental impact of the producers' markets can only be experienced at a moderate level due to the social maturity lagging that of the Western European.

The present valorisation of the market places in Hungary was brought into prominence again because of the expansion of the consumer knowledge and due to the international trends. The health conscious and environment conscious purchase mean frequently the same as spending leisure time, which can be well attached to the motivations of tourists especially where the antique objects and antiquities are part of the supply. The majority of the market commodities are represented by foodstuff products; traditionally, fruits and vegetables, baked goods or processed goods (unique jams, special sausages). All these give a chance to the direct acquisition of certain provincial gastronomy experiences as well (Fehér and Kóródi, 2008; Töröcsik, 2007, 2011; Williams et al. 2014; Sidali, et al. 2015).

The listed product types of rural tourism can be well connected to local product development and local economy development as well. Knowing the local producers and being able to trace the product's supply chain provide confidence to the consumer, so preferring the local producer and the local product will lead to the stimulation of the local economy since it can displace the mediator actors from the supply chain (Csíkné Mácsai, 2014; Szabó, 2014). Nevertheless, on the contrary to the local inhabitant, the tourist does not know the local producer, the consumer confidence in this case can be strengthened by the direct connection. Dogi et al (2014) unequivocally revealed that the local, unique products can be purchased the most easily by visiting the casual markets or through other direct selling points. Nevertheless, in the markets, it presents difficulties when on the one hand, the very different, often peculiarly tasting and packaged, high quality products appear in the market raising the attention of the customers, but on the other hand, these products have only a very limited access, both in time and space. The consumer knowledge, the market appearance of the products, the consciousness of the social groups and the motivation, free time and discretional income, all influence the possibilities for the sales activity of the producer. The consumer expectations are influenced 
and altered by the characteristics of the consciousness (margin of profitableness, transport opportunities) and the habit of the tourists as well (Dudás, 2011; Tomcsányi, 1993; Pizam and Mansfeld, eds. (2000). In turn, the competitive disadvantage of the producers can be decreased even with one special product. But we also have to see that in some cases, the consumers experienced the signs of oversupply at some home made products.

In the near past, in the sample area - according to the regional development concept - numerous producers' market opened its gates with local producers in order to achieve an improvement of their life quality. The partly different product supply of different markets at the Balaton region attracts different social groups, which would differentiate the consumer judgement of the markets as well. In the region besides water tourism, the new novel product elements offer a chance for the extension of the already existing attractions giving a place to the peculiarities of the gastronomy of the Balaton region (wines, fish meals, spices and virtuous plants).

Besides the traditional exchange of commodities, some markets possess additional values, programmes (music and folk dance programmes, handcraft exhibitions, buffets and temporary caterers) with touristic attraction as well, that is why the producers' markets of Káptalantóti, Tihany, Gyenesdiás or Hévíz are prominently popular among the visitors of the region (Fekete, 2013; Oláh, 2013-2014). The valorisation of the gastronomy and the local products is also supported by those personal researcher observations which bear evidence of the purchase of the raw materials for meals, candies and other foodstuff in producers' markets (such as Balatonboglár, Balatonfenyves).

In our geographical framework, based on the operative database of the Hungarian Chamber of Agriculture, altogether 28 producers' markets are registered. The real producer and consumer demand for them could provide aid to moderate the mentioned negative trends since significant differences can be detected in their spatial allocation (Table 1) ${ }^{3}$.

Tab 1. The spatial allocation of the producers' markets. Source: Nezdei, 2018

\begin{tabular}{|l|c|c|c|}
\hline & $\begin{array}{c}\text { Northern part } \\
\text { of the lake }\end{array}$ & $\begin{array}{c}\text { Southern part } \\
\text { of the lake }\end{array}$ & $\begin{array}{c}\text { Total around } \\
\text { the lake }\end{array}$ \\
\hline $\begin{array}{l}\text { Markets in the background } \\
\text { settlements of the Balaton region }\end{array}$ & 10 & 4 & 14 \\
\hline Total & 18 & 10 & 28 \\
\hline
\end{tabular}

Therefore, the analysis of the market places at the Balaton region served the aim to be able to determine their role in the tourism sector and also their indirect rural and regional development impacts in the Balaton region. The opening of the markets can actuate the producers to the local marketing and the diversification of their farm, while the consumers to seek for the local products and to put the local farms into position ((„Farm to the table”). We analysed the aim of the markets from consumer, market manager and producer aspects (see methodology). Either we take into consideration the added value or the unique, quality product supply, these markets could represent a peculiar alternative to keep the population in place and mobilize the local economy. But how exactly do the consumers interpret the markets? With what aim are the producers' markets operated? What kind of perspectives can the market operators see in their market? What kinds of factors motivate the marketers and why exactly they choose the producers' markets? In our study, we focus on the present and future development ambitions of the market places through the inherent rural and regional development opportunities of the Hungarian aspects.

\footnotetext{
3 The statistical data for the producers' markets in the region by $28^{\text {th }}$ December, 2017: 20 producers' market, out of which 16 can be found in northern and 4 in the southern shore (according to data of the homepage of the Hungarian Chamber of Agriculture). In the present case, the harmonisation of the databases carried out by further offices and organisations was not prepared, but according to the research experiences, we can presume a higher number of producers' markets.
} 


\section{Methods}

\subsection{Methodology elements/types}

Writing the present paper, we used empirical and secondary methodology elements. The sample area of our study was the Balaton Accentuated Tourism Zone (BATZ) covering 180 settlements (according to 2015 data). This topic has been chosen with the aim of providing an answer, an alternative to the internal conflicts of the region (only a few occupation opportunities in the background areas, periodic labour possibilities, pricing, urbanisation, change of land use, ageing society). Within the framework of this paper, the Balaton region and the area of Lake Balaton are synonymous expressions to BATZ.

During the empirical research of the authors, the already available national databases $\left(\mathrm{HCA}^{4}\right.$, $\mathrm{NFCSO}^{5}, \mathrm{RIAE}^{6}$ ) have been clarified by personal enquiry. Due to this, the database of the market place types of the Balaton region has been created. The questionnaire survey was carried out in 7 market places (Tapolca, Keszthely, Fonyód, Káptalantóti, Tihany, Siófok, Balatonfüred), of which the selection was based on the expected daily turnover, the spatial allocation and the opening period of time in the preseason, high season and the post season (in May, July and September, on the official market events). In the selection of the location, the waterside or background allocation and the comparability of the market types played an important role.

The respondent customers in the markets ( $n=454$; 2016; face-to-face method) were asked about the aims and motivations of the visit, the amount of money spent and their satisfaction with the market place (location, product, services, consumer peculiarities, selection). Among the methodological elements, open questions, categorised answers and 5 scale Likert scales were used. The concrete selection of the respondents was made by arbitrary sampling. The target group of the market visitors is strongly homogeneous, that is why the chosen sampling method cannot assure the representativeness by age, gender, region, settlement and education level. Despite all this, it can demonstrate the typical consumer characteristics of this sales channel and the different motivations behind the identical consumer decisions (Nezdei, Cs., Alpek B. L. 2018). Regarding the place of living, permanent inhabitants, tourists and periodic inhabitants appear alike among the visitors of the markets. This latter group between the permanent inhabitant and the tourist should be handled as so-called intermediate sample, since it shapes the consumer habits and the elaboration of innovative local products, both with the visit of the settlement and the market. It meant a difficulty for the primary methodology that the addressed persons mixed the survey with product selling, propagation of religious beliefs and fund raising, so the number of the respondents was only two-thirds of the effectively addressed market visitors. The residence of the respondents was distributed by the settlements and the sampling as the following (Table 2).

The touristic explanation of the market places appears in the management tasks as well. Besides the questionnaires filled by the market managers ( $n=42 ; 2016-2017)$, we understood these challenges also due to the interviews with the sellers and the managers and the content analysis of the online surfaces of the market places (web page, social media). The major topics of the phone call interviews were framed around the product range, the comprehensive consumer criterion, the number of the vendors, the market place opportunities and the financing possibilities. In the answers, the respondents reviewed separately whether they carried out aimed tourism developments or not. The respondents could give categorised and free association answers for the questions. In order to recognise the producers' opinions, personal and semi structured interviews were carried out $(n=6 ; 2017)$ and further free conversations $(n=24 ; 2017)$ where emphases was laid on rural development aspects, motivations and the exploration of the most preferred product groups by the consumers.

\footnotetext{
${ }^{4}$ Hungarian Chamber of Agriculure

${ }^{5}$ National Food Chain Safety Office

${ }^{6}$ Research Institute of Agricultural Economics
} 
Tab 2. The distribution of the residence of respondents by settlement and sampling. Source: Own research by Nezdei Cs. 2016

\begin{tabular}{|l|l|r|r|r|r|}
\hline & & \multicolumn{3}{|c|}{ Residence of the respondents (\%) } \\
\hline Settlement & Date & Locals & Non-locals & Unknown & Sum \\
\hline \multirow{3}{*}{ Balatonfüred } & May & $0.00 \%$ & $0.00 \%$ & $0.00 \%$ & $0.00 \%$ \\
\cline { 2 - 6 } & July & $64.52 \%$ & $35.48 \%$ & $0.00 \%$ & $100.00 \%$ \\
\cline { 2 - 6 } & September & $68.00 \%$ & $28.00 \%$ & $4.00 \%$ & $100.00 \%$ \\
\cline { 2 - 6 } & Sum & $66.07 \%$ & $32.14 \%$ & $1.79 \%$ & $100.00 \%$ \\
\hline \multirow{5}{*}{ Siófok } & May & $0.00 \%$ & $0.00 \%$ & $0.00 \%$ & $0.00 \%$ \\
\cline { 2 - 6 } & July & $68.00 \%$ & $28.00 \%$ & $4.00 \%$ & $100.00 \%$ \\
\cline { 2 - 6 } & September & $66.67 \%$ & $26.67 \%$ & $6.67 \%$ & $100.00 \%$ \\
\cline { 2 - 6 } & Sum & $67.27 \%$ & $27.27 \%$ & $5.45 \%$ & $100.00 \%$ \\
\hline \multirow{5}{*}{ Tapolca } & May & $53.57 \%$ & $39.29 \%$ & $7.14 \%$ & $100.00 \%$ \\
\cline { 2 - 6 } & July & $57.69 \%$ & $30.77 \%$ & $11.54 \%$ & $100.00 \%$ \\
\cline { 2 - 6 } & September & $70.00 \%$ & $26.67 \%$ & $3.33 \%$ & $100.00 \%$ \\
\cline { 2 - 6 } & Sum & $60.71 \%$ & $32.14 \%$ & $7.14 \%$ & $100.00 \%$ \\
\hline \multirow{5}{*}{ Káptalantóti } & May & $0.00 \%$ & $0.00 \%$ & $0.00 \%$ & $0.00 \%$ \\
\cline { 2 - 6 } & July & $3.85 \%$ & $84.62 \%$ & $11.54 \%$ & $100.00 \%$ \\
\cline { 2 - 6 } & September & $0.00 \%$ & $100.00 \%$ & $0.00 \%$ & $100.00 \%$ \\
\cline { 2 - 6 } & Sum & $2.08 \%$ & $91.67 \%$ & $6.25 \%$ & $100.00 \%$ \\
\hline \multirow{5}{*}{ Tihany } & May & $0.00 \%$ & $0.00 \%$ & $0.00 \%$ & $0.00 \%$ \\
\cline { 2 - 6 } & July & $0.00 \%$ & $100.00 \%$ & $0.00 \%$ & $100.00 \%$ \\
\cline { 2 - 6 } & September & $0.00 \%$ & $100.00 \%$ & $0.00 \%$ & $100.00 \%$ \\
\cline { 2 - 6 } & Sum & $0.00 \%$ & $100.00 \%$ & $0.00 \%$ & $100.00 \%$ \\
\hline \multirow{5}{*}{ Keszthely } & May & $76.47 \%$ & $23.53 \%$ & $0.00 \%$ & $100.00 \%$ \\
\cline { 2 - 6 } & July & $88.89 \%$ & $7.41 \%$ & $3.70 \%$ & $100.00 \%$ \\
\cline { 2 - 6 } & September & $77.78 \%$ & $22.22 \%$ & $0.00 \%$ & $100.00 \%$ \\
\cline { 2 - 6 } & Sum & $81.69 \%$ & $16.90 \%$ & $1.41 \%$ & $100.00 \%$ \\
\hline & May & $35.56 \%$ & $51.11 \%$ & $13.33 \%$ & $100.00 \%$ \\
\cline { 2 - 6 } & July & $23.33 \%$ & $70.00 \%$ & $6.67 \%$ & $100.00 \%$ \\
\cline { 2 - 6 } & September & $36.67 \%$ & $63.33 \%$ & $0.00 \%$ & $100.00 \%$ \\
\cline { 2 - 6 } & Sum & $60.00 \%$ & $7.62 \%$ & $100.00 \%$ \\
\hline
\end{tabular}

The methods of the empirical research were complemented with field photo documentation and the data elaboration was carried out by using a spreadsheet programme (MS Office Excel) and a GIS programme (ARCMap). The word cloud in the results chapter registers the mostly mentioned products which the consumers were principally missing. The font size refers to the importance of the product or its absence providing a base to the creation of a consumer-based product profile.

The classification of the marketplaces was made in concordance with Table 1, however, it has to be seen that there is a lack between the touristic development alternatives and the real capability of some marketplaces. There were only 24 marketplaces which had a chance for touristic development. The other ones did not have the minimum criteria such as for instance, concerning infrastructure, product profile, etc.

The secondary methodology consisted the revealing and secondary analysis of the theoretical literature and the regional development materials. The professional literature and regional development documents of rural, village and agrotourism, the agrarian and economic literature of the market places and the literature and regional development documents related to Lake Balaton guaranteed the scope for our secondary researches. Out of the development materials, mainly the connection between the agrarian and the background areas and the objectives and programs of the development organisation were taken as a basis. Nevertheless, the Hungarian literature dealt with the retail relations, short supply chains and sustainable rural development alternatives, 
but the overdue introduction of these research areas apparently represent a rather spare literature background. On the contrary, to the international context the tourism relations of the market places are less revealed in the Hungarian context.

We followed with attention the image formation, which is significant from the point of view of tourism, through the marketing activities and in some cases, through judicial combats. The related data were revealed from the electronic press (web 2.0 contents, web pages, social media etc.) and from the publications and appearances of the public bodies of the settlements.

\subsection{Terminology}

The determination of some applied concepts would make the understanding of this paper easier. The consumer, buyer and purchaser are synonymous concepts in this case; market should be defined as market place in all cases. The market as retail channel can be differentiated to several types in the Hungarian legal background ${ }^{7}$, basically categorising the traditional and the local producers' markets. The present research interprets the markets according to the legal framework.

- The traditional market is "such a building, building complex or area where several individuals practice permanently or regularly usually on a daily, sometimes weekly basis, retail activities." (Authors' translation)

- The local producers' market is "such a market where the small producer realizes his/her agrarian or food industry product produced in his/her farm situated in the county of the market, or in the $40 \mathrm{~km}$ zone of the market or in the case of Budapest, in all regions of the country." (Authors' translation)

The local producers' market appeared in the domestic legal environment in 2011, which, due to the simplified conditions in several years exceeded 250 locations in the country. From the spatial perspective, they concentrate in Budapest and in the Balaton region. In the latter one, the favourable sales opportunities are strengthened by the tourism scope and so the high ratio of visitors and tourists. Besides this, we should take into consideration that a considerable amount of inhabitants from the capital and its agglomeration, own properties in the Balaton region who definitely look for the milieu of the local producers' markets. A strong fluctuation is characteristic of the producers' market type, which can be traced back to the periodic consumer demand and the altering amount of producer supply. Such market places were developed in the Balaton region that possesses real spatial organising force, also carrying the signs of a tourism attraction. Such locations are the producers' markets of the already mentioned Hévíz, Gyenesdiás, Káptalantóti or Tihany.

In the Hungarian every day practice, the legislator displays other market and selling opportunities such as the market halls, markets or casual events or festivals (extemporal selling). Among the periodic or extemporal market like events, we find the flea market, the second hand market, flower market and the bio market. These latter ones with their specialised or unique products provide an attraction to those who do not aim to purchase conventional or mass products. Within the framework of the present study, we make an attempt to theoretically classify the producers' markets. The difficulties of this task can be originated from the fact that there are very diverse types of markets with numerous motivational, organisational, product profile, infrastructure, or target group differences.

\footnotetext{
${ }^{7}$ The related laws: the 2005. CLXIV. Act on Commerce; 210/2009. (IX. 29.) Government regulation; 55/2009. (III. 13.) Government regulation.

8 2005. CLXIV. Act $2^{\text {nd }} \S .19^{\text {th }}$ point

${ }^{9}$ 2005. CLXIV. Act $2^{\text {nd }} \S$. $5 \mathrm{a}^{\text {th }}$ point
} 


\section{Results}

\subsection{The regional situation of the markets}

\subsubsection{The consumer basis for the market place classification}

The reviewed consumer query gives a basis to analyse and redefine the functions of the market places in the sample area. $83.26 \%$ of the respondents visited the periodic or permanent market place in order to buy daily products so they understand these places as examples for the short supply chains. Nevertheless, at least $25 \%$ of the consumers indicated some secondary role as well (recreation. family programme, but very few indicated the markets as direct tourist attractions which would suggest an experience-like purchasing) (Figure 1.).

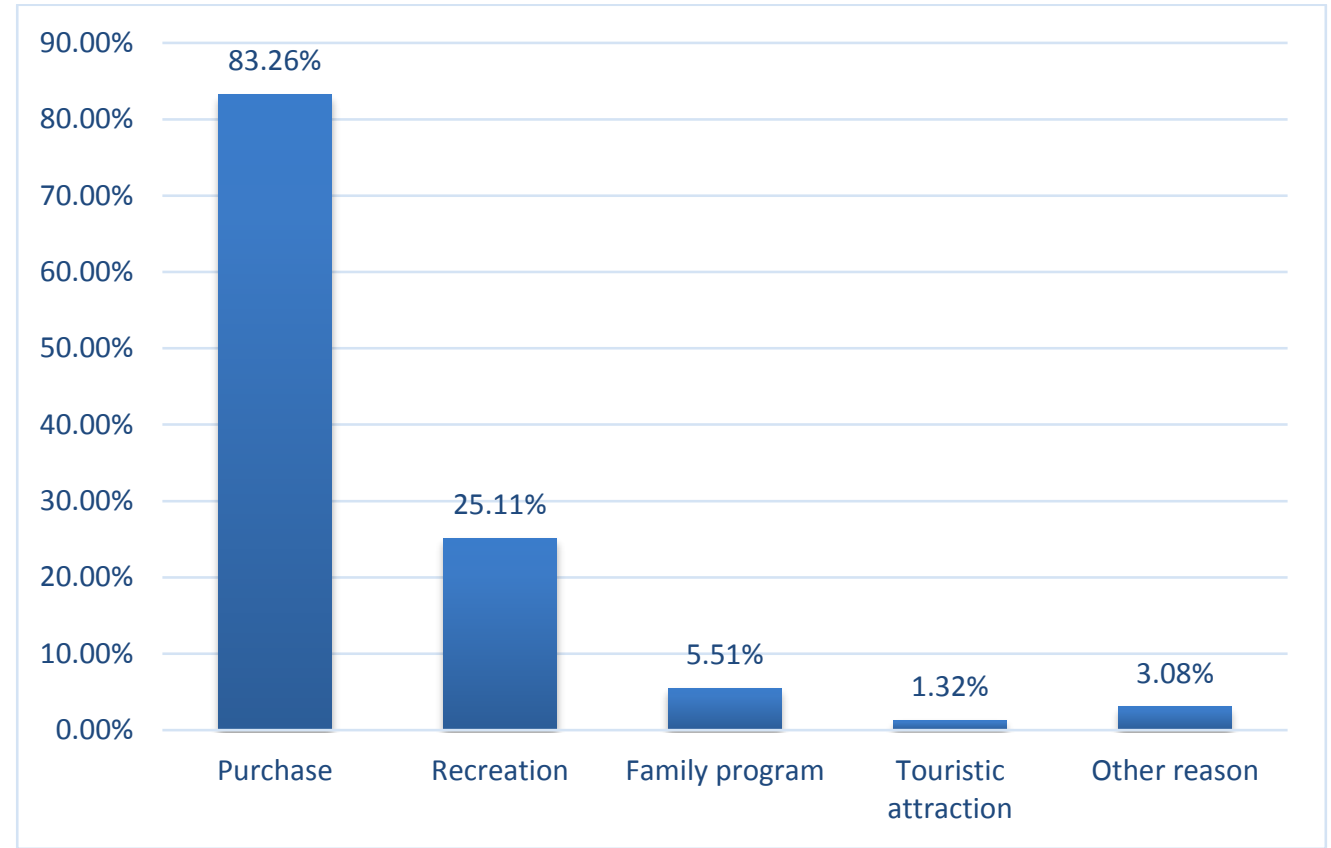

Fig 1. The aims of visiting the markets. Source: Nezdei, Cs. 2018

Nevertheless, the consumers see the markets as a possibility for purchasing. On the whole, the statistics do not certify the concrete aim of visiting a touristic attraction. The reason for this low rate is double: On the one hand, in the response, tourists were only partners in a very low rate (around $2 \%$ ), and on the other hand, we handled the market types together. The willingness for responding was further worsened by the fact that during the recreational activity, the personal questionnaire query was disturbing. They identified the survey with direct marketing tools, targeted product purchasing attempts which also led to very low number of tourists in the sample.

The differentiation of the markets is influenced by the potential target group and/or product profile. During the survey, the number of those respondents was high who possessed their own properties in the region (such as vineyard parcels, holiday homes or family houses) and they use them periodically in order to spend their free time there. The property owners generate a seasonally permanent demand for the producer supply. All this eventuates that the product demand mainly tends towards daily consumer products rather than the specialised products that can also be taken as presents. In all the analysed locations, the most frequently purchased goods were the fresh vegetables and fruits and horticultural products in the product profile. The demand was generated the most by the greenness and the quality of the product giving emphasis for the role of the short supply chain. The appearance of the consumer consciousness was shown that $21 \%$ of the respondents missed mainly the local, Hungarian, homemade or chemical free foodstuff (Figure 2), which will favour the viability of the Hungarian alternative foodstuff networks (e.g., producers' markets) in the long run. 


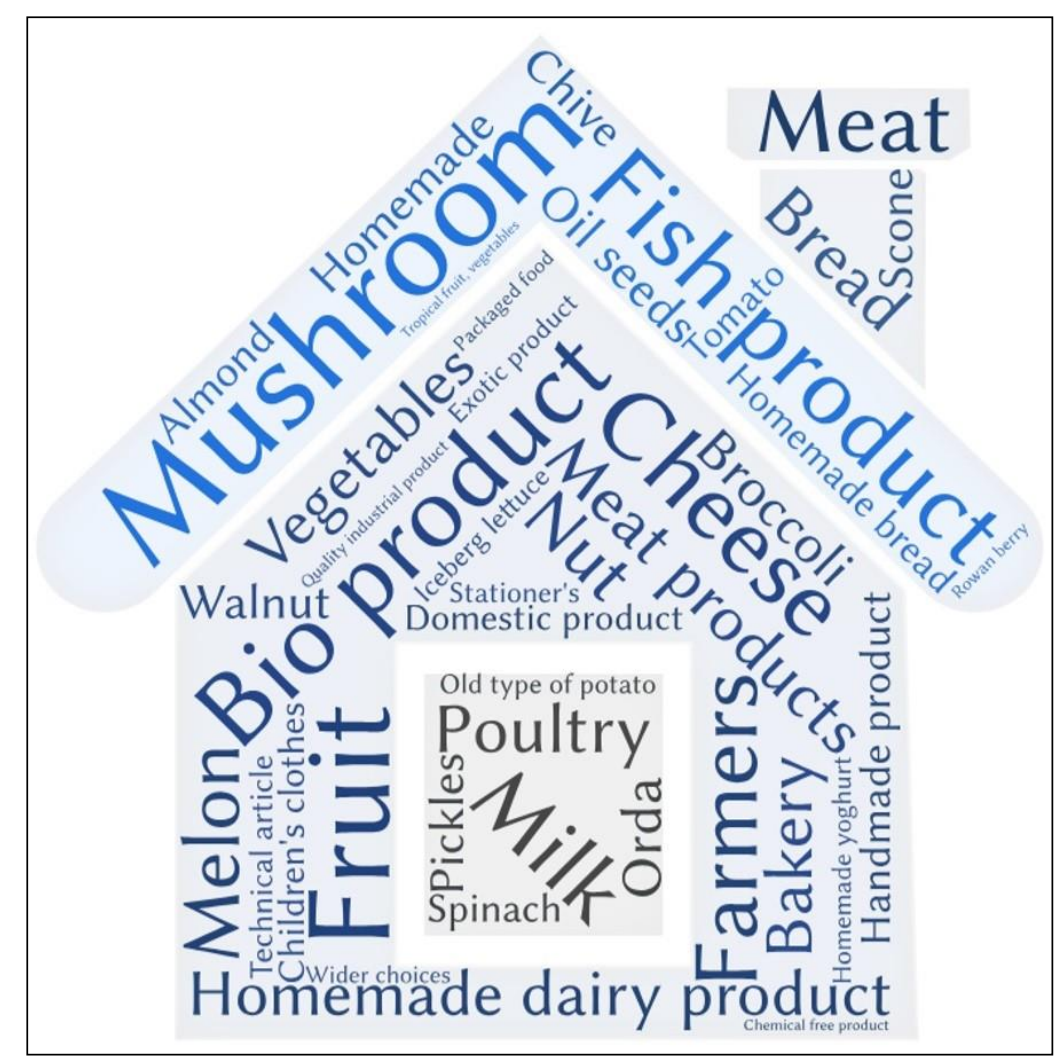

Fig 2. The most missing products in the markets. Source: Own research by Nezdei, Cs. 2016

\subsubsection{Intermediary actors as the organising forces of rural development}

The intermediary role between the producer and the consumer is provided by the market operators in the market places. The decisions of the intermediary side directly involve the actors so understanding their aims and development ideas fulfils an important aspect in the research. Based on the results of the questionnaire survey of the operators, the development into a tourism attractions appear in nearly two-thirds of the cases. In one-third of the locations, the established local market provided the physical framework for the assembly of the settlements' communities, however they stand clear of tourism. The infrastructural development objectives, for which the intermediary actors are responsible for, appeared in the producers' market with only weak financial resources; in the newly built or reconstructed markets, such need was not indicated.

The market operators fulfil such intermediary bridge function between the producer and the consumer, which save time and energy for the producers. The intermediary person or organisation can advance the producer's sales activities with establishing the infrastructural conditions, following with attention the regulatory criteria or functioning marketing activities and promotion. Due to the administrational burden, the time demand for the preparations of the producers is a frequent source for conflict. In stating the case for the development directions, the uncertainty of some operators was caused by the fact that the maintainer and the operator were different but they did not receive up-to-date information concerning the future plans.

Besides the consumer books ${ }^{10}$, the measurement of the producer and/or consumer feedback would provide factual knowledge for the operators, but based on the interviews with the operators, they do not use any concrete methodology to measure the satisfaction in order to keep track of their market. Its introduction in the tourism purpose developments would improve both the efficiency of the product profile and the infrastructural developments. It would be especially effective in the case of those who dispose electronic interfaces because the opinion of the target group, rather avoiding the market, would be knowledgeable. Nevertheless, the producers can

10 Through the consumer book, the purchasers can complain and can record their satisfaction, opinion and proposals in a written form. (https://www.fogyasztovedelem.hu/Varia_x/panasz.htm, 2017-06-29) 
personally tell their difficulties and problems related to the location, the judgement of the consumers can be caught in their non-attendance or in their comments on the electronic interfaces. The operators listed among their development aims, the extension of their market with further products, which is baulked by the absence of their producers from the closer region (Nezdei and Mohos, 2017). According to the operators, agricultural activity and product processing is less practised at the waterside areas, which makes the local product expansion difficult. But on the whole, based on the product range, the markets are well provided and satisfy the needs for foodstuff of the local consumer groups.

\subsubsection{Producer and consumer feedback}

The producers evaluate the markets differently if they form their opinion about the realized product type or the size of the market. The greater consumer turnover of the traditional markets diverts attention from the local products (the price is more important than the taste and the quality of the product) and the direct connection between the producer and the consumer. The local producers evaluate the producers' markets as a more advantageous opportunity where the consumers seek for anthropocentricity, real, fresh and high quality raw material or the accustomed tastes or novelties. The seasonal demand of the holiday makers led in many cases to the formation of annually recurrent consumer relationship. The reason for this is the need for high quality product deriving from the already known producer from a creditable source: during the holiday, the healthy sources for foodstuff are guaranteed by these market places. The smaller scale, often around 10 producers, makes an opportunity for the consumers to discover the fabrication and its secrets as well. The differences of the market places divert the producers' markets seemingly into two major directions: on the one hand, the purchasing of the foodstuff products and on the other hand, towards the direction of the joint creation of product and leisure time. Where the market place plays a role in spending leisure time as well, the markets appear as factual tourism attractions; however the regional consumer groups provide no exact answer for this because of the already mentioned reasons.

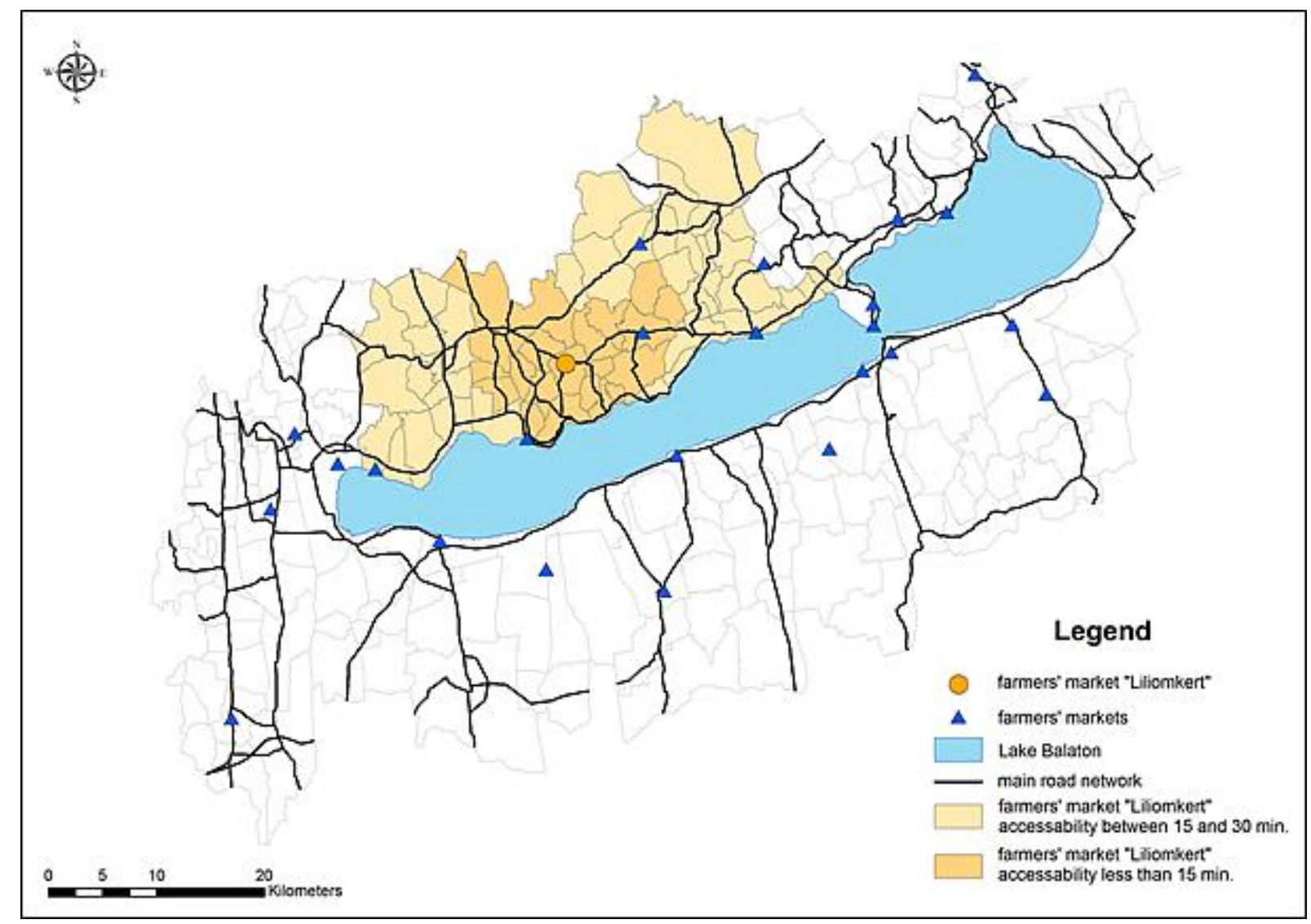

Fig 3. The allocation and accessibility of the Káptalantóti producers' markets. Source: Based on CSO and NFCSO data Edited by Horváth, $Z$. 
The consumer experiences are primarily based on the opinions of the local or regional population because the non-local inhabitants (tourists, property owners; 17.62\%) were disturbed by the personal questionnaire survey in their leisure time. From the point of view of the respondents, the primarily aim was the accessibility of the settlement (market), which calls the attention on the necessity of the infrastructural developments of the public traffic (Figure 3). The availability of parking opportunities nearby the markets is emphatic. Despite the creation of the parking places, the vehicles form traffic barriers in the summer months around the markets.

\subsection{The theoretical ways of the touristic development of the producers' markets}

For the classification of the 28 producers' markets, besides the utilisation of the result of the primary data collection (producers and consumers), the experiences of the field observations were also used. We identified and classified those factors, which in compliance with the market places of the touristic regions can appear as independent tourism attractions. The success criteria and factors are the following:

- Supply elements:

- Infrastructure: According to the judgement of the consumers, the adequately constructed physical infrastructural elements are a basic requirement for the market places. They emphasized the accessibility and identification of the market, the creation of parking places, the look of the market stands, the correction of the road surfaces, the demanding formation of the washrooms and the spacious transport opportunities. The development proposals of the producers are consistent with $51.1 \%$ of the consumers' opinions.

- The quality of the product supply and the spectrum of the composition: $28.19 \%$ of the respondents made product recommendations out of which the supply range and the presence of the high added value were highlighted. The missed product type and the higher added value indicate practically the same directions. Preferring the local and the Hungarian products would be able to favour the local producers on the contrary to other sales channels and the import products.

- Marketing activity: As long as the local products are present in the competently wide spectrum and high quality with high added value, the producers' market, so familiarizing the producers and the local products, can be launched. In order to address the increased temporary population of the holiday resort, the operators of the market places primarily try with the traditional printed throwaways and brochures. $42 \%$ of them are present with their own web page or touristic web page of the settlement; the interface of the social media which is also suitable for giving opinions is used by hardly half of them. All these surfaces are maintained and uploaded with fresh, actual content by only a small minority. Besides the homepage of the settlement, the Liliomkert market analysed in this paper is present with its own social media surface and numerous blogs were made about it as well.

- Demand: The demand is constituted by the holiday home owners, the local population and of course the visitors of the lake. In 2016, altogether 5,451,600 guest nights were spent by $1,692,124$ tourists in commercial accommodations in Lake Balaton (Hungarian Tourism Agency 2017), presenting a potential opportunity for a higher number of visitors of the marketplaces. The tourism demand grew continuously in the last 8 years; the number of guest nights increased with $28.8 \%$ compared to 2010 . There are significant differences in the seasonal distribution of the tourism demand, which is caused by further inequalities of the regional differences of the product composition. The timely distribution of the guests is more balanced around the western basin of the lake where we can see the altering tourism product composition in the background. The medical spas of Hévíz and Zalakaros provide highlighted attractions even with international importance and so we find them among the most visited settlements of Lake Balaton. Because of the cultural and active tourism supply of the Keszthelyi Bay, the visitors are attracted all year round, while in Badacsony, the traditional grape and wine culture causes the more balanced timely distribution of the demand. 
In order to develop the markets to tourist attractions, besides the presence of the adequate infrastructure, the quality local products, the potential visitors/consumers and the intensive and segmented marketing communication, further steps are necessary. The uniqueness of the markets will be the awareness-raising factor which will help the visitors in the necessary identification. Besides this, it needs to possess an experience promise and should provide the expected experience for the guests. So whether we develop the traditional or the local producers' markets, it needs to display such special features and characteristics, which are able to target a determined consumer group with effective organisation and marketing in advance. We can appoint three well differentiated directions in the tourism development of the market places, which are:

1) The market as a programme (music and dance programmes) (e.g., Hévíz, Zalakaros, Gyenesdiás...);

2) rural development - gastronomy (local eating houses and wine supply) (Káptalantóti, Balatonfenyves...); and

3) the aggregation of the landscape and the local product (Tihany and the lavender).

It is important to mention that most of all the initiation of a local programme or further entertainment opportunities could contribute to the tourism attraction development, but this idea was only supported by $2.42 \%$ of the respondents. The low rate was because of the high number of the local inhabitants and the low willingness of responding.

Out of the upper mentioned development perspectives, we analyse the rural developmentgastronomy direction in our study. It is mainly differentiated from the market as a program development directive by the product supply and the consumer motivation and from the aggregation of the land and the local product, its direct identification due to the product. Out of the three featured development directions, we can follow the example of Tihany with the greatest difficulties, since applying the unique land-characteristic symbol, the consumer perception is based on the produced product and the landscape value. In the Hungarian reasoning, Tihany is synonymous with the lavender, so in the analysed region, only a narrow scope of settlements could adapt this direction as a modern rural development tool.

\subsection{Rural development and gastronomy: on the track of rural values}

In our theoretical category, rural development-gastronomy, the example of the Liliomkert in Káptalantóti is outstanding. Káptalantóti, allocates only $8 \mathrm{~km}$ from the shore of Lake Balaton, gives place to maybe the most popular market of the Balaton Uplands, named Liliomkert (Lily garden). It was established 10 years ago with a strong intention on rural development with the governance of an enthusiastic local citizen. The market, which is now functioning on an organisational basis, is visited by people from numerous cultural scopes not only by Hungarians but foreign visitors as well. In the interest towards the Liliomkert, we can find the appearance of the highly qualified inhabitants (artists, doctors, actors) migrating from other areas of the country to the Tapolcai and Káli Basin and their consumer consciousness and solvent demand. The demand of the location ${ }^{11}$ annually managing 200000 persons can effectively serve the differentiation of the local economy for the local and regional producers.

All this makes a direct impact on the formation of the land use and the small scale farming (apparently the majority of the agricultural and foodstuff products are made with chemical free production - that is why the markets are often denominated ${ }^{12}$ as "bio"). The attraction of the rich landscape features and the anthropocentricity of the area make the elderly to settle down causing numerous social impacts (ageing social structure, creation and conversion of the healthcare system). The value of the marketplace is increased by the fact that the visitors can not only buy

\footnotetext{
11 Settlement council of the Local Government of Káptalantóti: Data published in a report. See file:///C:/Users/User/Downloads/2015.11.24.\%20jegyz\%C5\%91k\%C3\%B6nyv\%20NY.pdf, 2017. 12. 31.

12 Because of the characteristics of the products, it can eventuate that these markets are inaptly called bio markets. In Hungary, real bio market functions only in Budapest, Miskolc, Szeged, Békés and some more significant settlements (Source: Nezdei, Cs. 2018. (manuscript)).
} 
the high quality and safe foodstuff products but on the breathing spaces of the marketplaces, they can make a pleasant family or friend meeting, or can eat lunch or local wines featuring the Hungarian tastes (Nezdei, 2016; BIKN Kft. 2017).

For the potential guests, the relaxed atmosphere and the supply of the guest caterers provide an extra attraction for spending their free time. The homely atmosphere of the producers was continuously broadened with newer members serving excellent local foodstuff and the supply of the handcraft products, and vintage, antique objects are also constantly enriching the supply of these places. The broadening of the range of the producers desired the increase of the space of the markets which sometimes decreased the size of the pitches of the individual producers along the same rental costs. The homely atmosphere of the range of the producers still remained, but out of the regular visitors of the market, many noticed that the market lost from its earlier authenticity. The whole year long functioning of the market means predictability for the consumers since they can buy fresh foodstuff and old-new household objects (even presents) every Sunday. Today, the conscious, healthy and quality ensured products also came into prominence in the scope of the consumers (local population, visitors, tourists) of the Liliomkert. The popularity of the market is well indicated that in the recent past, its smaller version was introduced in Budapest, which however was not maintainable due to the subsidiary costs. Based on the example of Káptalantóti, the Liliomkert Kamra Veszprém Ínyenc Piac (Lily Garden Chamber Veszprém Gourmet Market) created in 2017 also provides a chance as a community space to buy local, handcraft foodstuff nearby to the Balaton.

The popularity of the Liliomkert was shadowed by the judicial combat deriving from the land use and the construction of the basic infrastructure needed for the functioning of the local producers' market (e.g., water draw-off opportunities, the allocation of the waste bins etc.) (Molnár, 2015; Lantos, 2016). The business organisation and then co-operative registered as a seat in the area was deleted in 2015. Apparently, a co-operative ${ }^{13}$ is functioning officially in the area. In the parcel next to the Liliomkert, a producers' market was established and officially registered, possessing the necessary admissions, which is only different from the original for the visitors by the outlook of the pitches and the characteristics of the road surface (Figure 4). According to the operator of this producers' market, it was opened because of the greatly increasing demand and the producers who were crowded out from the Liliomkert.

The two markets provide a rich and deep range of supply together for the visitors. Their aim is to broaden the market in a way to give an answer to the consumers' needs and also providing a location and opportunity to the local producers and craftsmen in order to be able to take their products to a market. The facilitated procedure of the local producers' market gave the proper method for the physical formation of the market as compared to the licensing procedure of the wholesale markets. The two markets provide a place for 350 producers in the whole year serving the markets need $65 \%$ permanently and $35 \%$ temporarily. The proportion of the producers' answers was $40 \%$, the consumers' answers was $10.57 \%$ on this marketplace.

Based on exchange of experience, further market operators also made an attempt to adapt the market place model of Káptalantóti in the region, but the special atmosphere of this market makes it unique so it can be hardly reproduced. The relocation (the example in Budapest or in Veszprém) of the Liliomkert cannot assure the same milieu the visitors are used to. Nevertheless, the markets in Káptalantóti are prepared for compromise and co-operation. The land use requalification for an expansion is not possible by the power relations of the settlements. With the development of the market, the deficient authenticity can become questionable as well. For their popularisation, the locations use web pages and social media so they also keep their separation in this respect.

\footnotetext{
${ }^{13}$ According to the firm information database operative on 23 $3^{\text {rd }}$ November, 2017.
} 


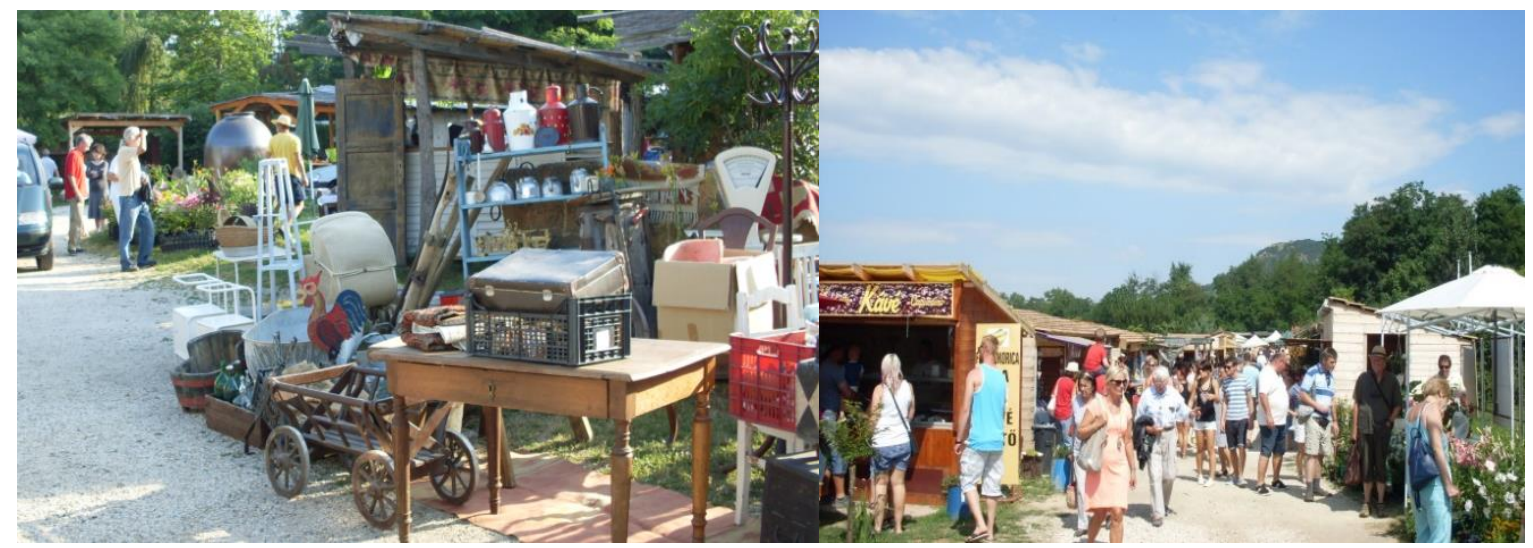

Fig 4. A snapshot about the Liliomkert and the producers' market of Káptalantóti. Photos: Nezdei, 2016

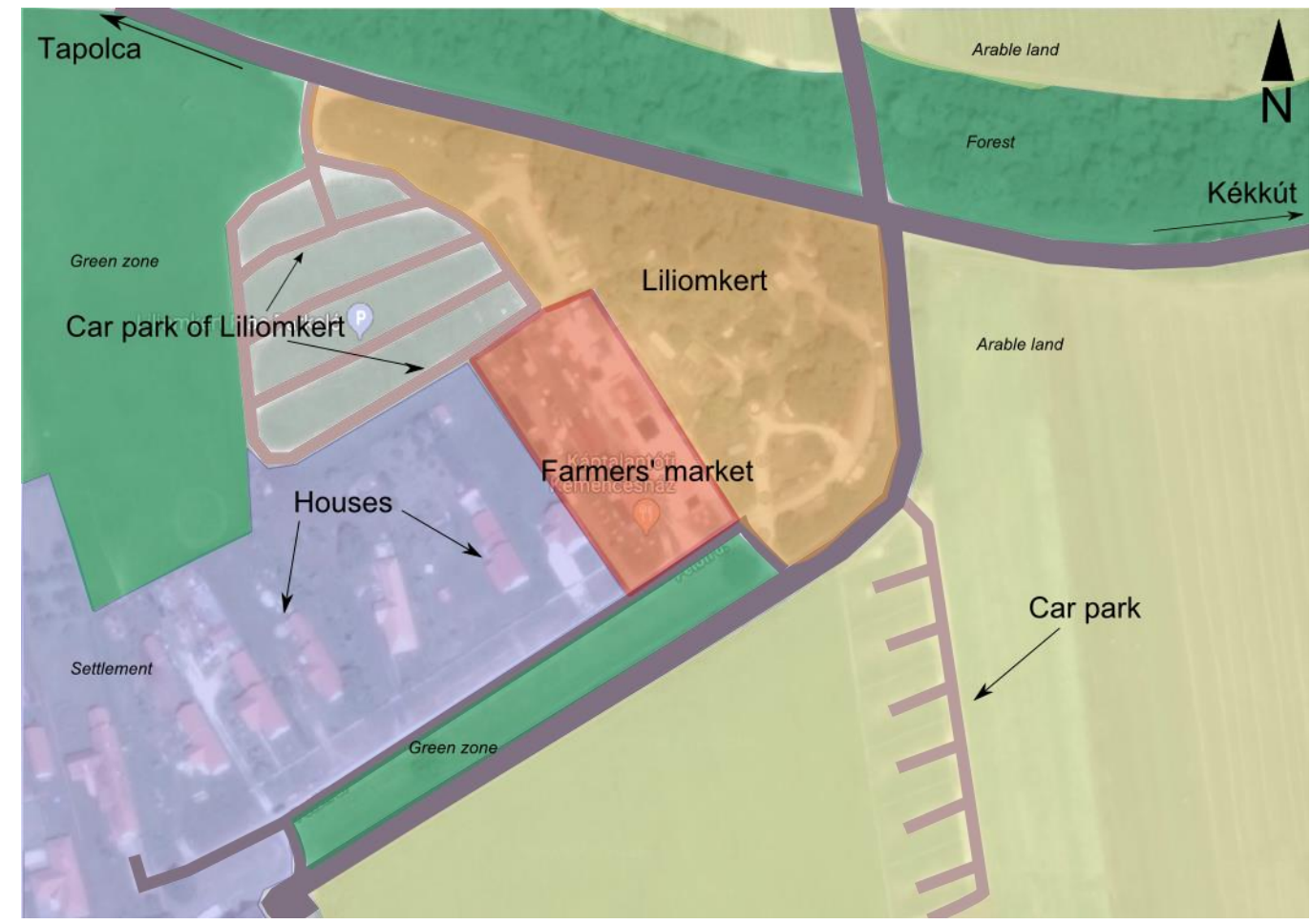

Fig 5. Market places functioning in Káptalantóti. Legend: area indicated with red: official producers' market; area indicated with yellow: Liliomkert. Ed.: Nezdei, 2017

\subsection{The market place as tourism potential}

The accessibility of the market can be a factor for success. Therefore, in the analysis, we paid attention on the traffic position and the accessible number of visitor as well. From a transport geographical point of view, the Liliomkert can be accessed as a potential tourism location within 15 minutes from 19 settlements by car (Figure 3). In 2016, 104912 guests were accommodated in the nearby settlements of the market but in their distribution, we can find significant spatial concentration, since 43,825 persons were accommodated in Tapolca (42.06\%) and 40,744 persons in Badacsonytomaj (39.1\%). Visiting the market is mostly favourable for car owners and cyclists, because at the time of the market, there are only minimal public transport solutions and the market is situated about 500-750 metres distance ${ }^{14}$ from the stations. The affectation of the market is well indicated by the fact that the parking places are straitened and the minor roads are crowded, significantly making difficulties for transport in the summer

\footnotetext{
${ }^{14}$ The measured walking distance of the two nearest bus stopping points of Káptalantóti (Bácshegy and the Káptalantóti culture house). On the market day, there is one line in the morning hours and four in the afternoon/evening (according to the schedule as of 14. 01.2018).
} 
months in the case of this market as well (Figure 6.). Taking into consideration the rural development aspects, the Liliomkert has no competitor in the region based on its product supply, food safety and job creation, nevertheless keeping the population in the region ${ }^{15}$ is the motivational background for many other local initiations. The market places fulfil a secondary community shaping role as well, so they give a chance to reinforce the local social network.

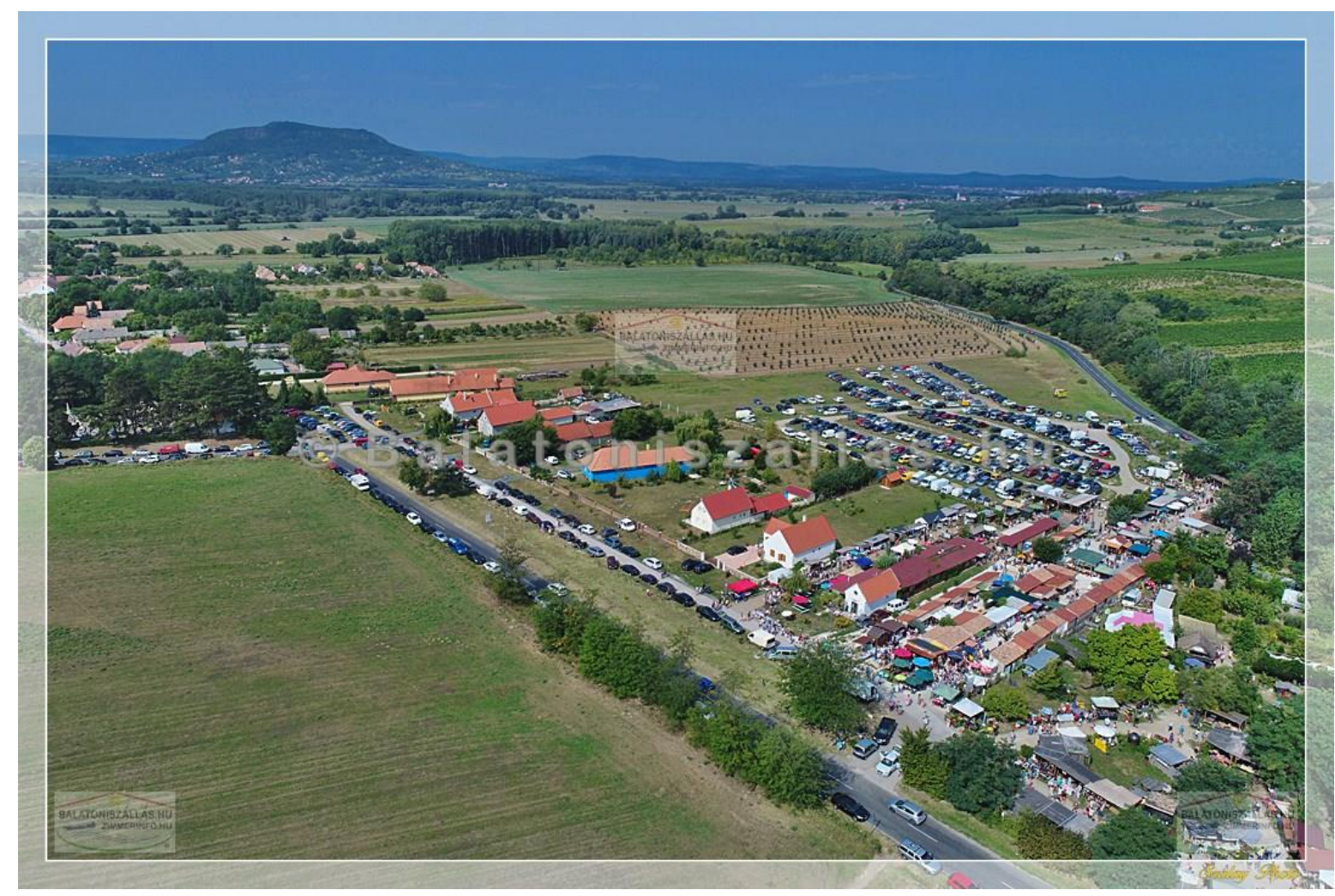

Fig 6. An average Sunday traffic in the local producers' markets of Káptalantóti.

Source: http://www.zimmerinfo.hu/kaptalantoti/pictures/kaptalantoti_liliomkert_legifoto.htm, 2018. 02.02.

Instead of tourism development, the operators of the producers' market in Vászoly put the practice of handcraft traditions and the introduction of the knowledge of the artists and craftsmen into focus. All this could be a good practice to establish and keep internal cohesion.

The example of the Liliomkert is open for most of the producers' market of the holiday region. Its success factor can be the community based organisation and reasoning which can improve the assertion of interests of the individual either if it is a supplier activity or even the establishment of a "real" market.

\section{Conclusions}

During the primary data collection and the field trips, we identified three possible ways for development out of which we demonstrated the rural development direction by highlighting the Liliomkert market. Besides the strict selection of the vendors, these producers' markets have active marketing activity as well, which can be seen in their attendance and also by the fact that the Lilomkert market became an active member of the gastro map of Lake Balaton. Out of the certain development directions of the holiday resort, as a further research direction, we can highlight the promotion of a trademark qualifier system. Especially in the case when there is a higher demand to sell outside the region.

\footnotetext{
${ }^{15}$ As many markets as many aspects and motivations since we can state that the market can fulfil a role as the meeting point of an already evolved mass of people which can also be established by a religious organisation (Calvinistic Congregation of Szólád - Provincial Church Market).
} 
Due to this, besides the theoretical surveys, it would bring together understanding each other better, the local producers and the potential consumers in practice. This latter ambition is further strengthened by the organisational development opportunities of the local actors. We suggest that the market management has to pay attention to the development of marketing activities as much as possible to reach the target group more efficiently. It is one way to expand the number of visitors. For locals, the direct marketing tools can spread the information in form of brochures, catalogues, leaflets or the appearance on local, regional events, promotions.

Besides the adequate infrastructure guaranteed by the market operators and the high quality local product producers, it is an important success factor that within a short period of time, as many as possible, visitors who already stay in the holiday resort shall be able to reach the market places. In the necessity of the accentuated Liliomkert market, more than 100,000 persons were concentrated from which, due to its authenticity and fame, it could benefit in the latter years. Its development impact is not only materialized through the farming of the lands but with the turnover as well generated for the settlement since the properties of the settlement are sold in a short time. Its spill over impact is jointly enforced with the conservation of the population, the provision of a kind of future for the rural inhabitants, and also the inhibition of the isolation of the elderly population.

\section{Acknowledgement}

The authors would like to express their special thanks to associate professor Majdánné, dr. Mohos Mária, PhD for her valuable contribution to this paper and also those market managers and producers who promoted our work with interviews.

Academic references

[1] Andrásfalvy, B. (2006). Vásár, búcsúvásár, sokadalom. In: Nagy, J. T. \& Szabó, G., eds., Vásárok világa (pp. 7-21). Szekszárd: Tolna Megyei Egyed Antal Honismereti Egyesület, Babits Mihály Művelődési Ház és Művészetek Háza.

[2] Berki, M. - Csapó, J. (2008). The Geographical Basis for the Development of Thematic Routes. In: Lóczy, D., Tóth, J., Trócsányi, A.: Progress in geography in the European Capital of culture 2010. Pécs: Institute of Geography, University of Pécs.

[3] Csíkné Mácsai, É. (2014). Közvetlen értékesítés a mezőgazdasági termékek piacán. (Ph. D. thesis). Gödöllö: Szent István Egyetem.

[4] Dogi, I., Nagy, L., Csipkés, M. \& Balogh, P. (2014). Kézműves élelmiszerek vásárlásának fogyasztói magatartásvizsgálata a nők körében. Gazdálkodás 58(2), 160-172.

[5] Domonkos, O., Nabybákai, P. \& Tomisa, I. (1991). Magyar Néprajz III. Kézmüvesség. Budapest: Akadémiai Kiadó.

[6] Dudás, K. (2011). A tudatos fogyasztói magatartás dimenziói. Vezetéstudomány 42(7-8), 47-55.

[7] Fehér, I. \& Kóródi, M. (2008). A vidéki turizmus fejlesztése. Budapest: Szaktudás Kiadó Ház.

[8] Fekete, K. (2013). Egy helyi gazdaság- és közösségfejlődési út a Balaton Kiemelt Üdülökörzetben: a termelöi piac. (Master thesis). Budapest: Eötvös Loránd Tudomány Egyetem.

[9] Gonda, T. (2013). A helyi termék reneszánsza. In: Gonda, T. ed., Helyi ízek Helyi értékek. Gasztrokulturális hagyományok a határ mentén. (pp. 23-41). Glavna: Horvátországi Magyar Vállalkozók Szövetsége.

[10] Hjalager, A., Kwiatkowski, G. \& Larsen, M. (2018). Innovation gaps in Scandinavian rural tourism. Scandinavian Journal of Hospitality and Tourism 18(1), 1-17. DOI: 10.1080/15022250.2017.1287002. 
[11] Kwiecinska-Zdrenka, M. (2013). Central and Eastern European Countryside from an international perspective (IRSA Congress in Lisbon, 2012). Eastern European Countryside 19, 277-285. DOI: 10.2478/eec-2013-0014.

[12] Nezdei, Cs. (2017). A vásárlói termékválasztás jellemzői a Balaton térség piachelyein a helyi termelői piacok. Élelmiszer, táplálkozás és marketing 12(2), 11-19.

[13] Nezdei, Cs. \& Alpek, B. L. (2018). Vásárlói csoportok a Balaton kiemelt üdülökörzet piachelyeinek példáján. Tér és Társadalom (Space and Society) 32(1) 145-160. DOI: 10.17649/TET.32.1.2874.

[14] Nezdei, Cs. \& Mohos, M. (2017). A piachelyek 21. századi vonzáskörzete - a Balaton Kiemelt Üdülökörzet esettanulmánya. Studia Mundi - Economica 4(3), 21-31. DOI: 10.18531/Studia.Mundi.2017.04.03.21-31.

[15] Piskóti, I., Dankó, L. \& Schupler, H. (2002). Régió- és településmarketing. Budapest: KJKKerszöv.

[16] Pizam, A. \& Mansfeld, Y. eds. (2000). Consumer behavior in travel and tourism. New York: Haworth Hospitality Press.

[17] Reisinger, A. (2010). A civil társadalom mint a sikeres vidék záloga. In: Glatz, F. ed., Sikeres vidéki térségek. Párbeszéd a vidékért (pp. 153-173.) Budapest: MTA Történettudományi Intézet - MTA Társadalomkutató Központ.

[18] Renting, H., Marsden, T. K. \& Banks, J. (2003). Understanding alternative food networks: exploring the role of short food supply chains in rural development. Environment and Planning A 35, 393-411. DOI: 10.1068/a3510.

[19] Sidali, K. L., Kastenholz, E. \& Bianchi, R. (2015). Food tourism, niche markets and products in rural tourism: Combining the intimacy model and the experience economy as a rural development strategy. Journal of Sustainable Tourism 23(8-9), 1179-1197. DOI: 10.1080/09669582.2013.836210.

[20] Spilková, J., Fendrychová, L. \& Syrovátková, M. (2013). Farmers' markets in Prague: a new challenge within the urban shoppingscape. Agriculture and Human Values 30, 179-191. DOI: 10.1007/s10460-012-9395-5.

[21] Syrovátková, M. (2016). The adoption of a local food concept in post-communist context: Farm shops in Czechia. Norsk Geografisk Tidsskrift - Norwegian Journal of Geography 70(1), 24-40. DOI: 10.1080/00291951.2015.1125942.

[22] Szabó, D. (2014). A rövid ellátási láncban rejlö lehetőségek és veszélyek Magyarországon. Acta Carolus Robertus 4(2), 109-118.

[23] Szabó, G. (2013). Helyi termékek és terroir termékek, mint attrakciók a turizmusban. In: Gonda, T. eds., Helyi ízek Helyi értékek. Gasztrokulturális hagyományok a határ mentén (pp. 1-18). Glavna: Horvátországi Magyar Vállalkozók Szövetsége.

[24] Tew, C. \& Barbieri, C. (2012). The perceived benefits of agritourism: The provider's perspective. Tourism Management. 33(1), 215-224. DOI: 10.1016/j.tourman.2011.02.005.

[25] Tomcsányi, P. (1993). A fogyasztói értékitélet és a piacos termelés: Akadémiai székfoglaló. Budapest: Akadémiai Kiadó.

[26] Törőcsik, M. (2007). Vásárlói magatartás: Ember élmény és feladat között. Budapest: Akadémiai Kiadó.

[27] Törőcsik, M. (2011). Fogyasztói magatartás: insight, trendek, vásárlók. Budapest: Akadémiai Kiadó.

[28] Trunfio, M., Petruzzellis, L. \& Nigro, C. (2006). Tour operators and alternative tourism in Italy: Exploiting niche markets to increase international competitiveness. International Journal of Contemporary Hospitality Management 18(5), 426-438. DOI: $10.1108 / 09596110610673556$. 
[29] Williams, H. A., Williams Jr., R. L., Omar, M. (2014). Gastro-tourism as destination branding in emerging markets. International Journal of Leisure and Tourism Marketing 4(1), 1-18. DOI: 10.1504/IJLTM.2014.059257.

Other sources

[30] Balatoni Integrációs Közhasznú Nonprofit Kft. (BIKN Kft.) (2017). Rövid élelmiszerláncok kialakítási lehetőségeinek vizsgálata Somogy és Zala megyében. Siófok - Balatonfüred, 131 p. Közremüködött: Saturnus-M Bt., Keszthely.

http://agrishort.eu/sites/default/files/file/agrishort tanulmany bifu.pdf. Last viewed on November 16, 2018.

[31] Balatoni Integrációs Közhasznú Nonprofit Kft. (2014). A Balaton régió fejlesztési irányai, dokumentumai 2014-2020. http://www.balatonregion.hu/aktualis-fejlesztesidokumentumok. Last viewed on September 19, 2018.

[32] Balatoni Integrációs Közhasznú Nonprofit Kft. (2014). Balaton Stratégiai Program. 2014. 10. 30. http://www.balatonregion.hu/aktualis-fejlesztesi-dokumentumok. Last viewed on September 19, 2018.

[33] Fogyasztóvédő és Érdekszövetség Alapítvány: Milyen panaszlehetőségeink vannak? Hova fordulhatunk, ha megkárosítanak? https://www.fogyasztovedelem.hu/Varia x/panasz.htm. Last viewd on June 29, 2017.

[34] Hungarian Tourism Agency (2017). Riport a Rekordévröl 2016. http://szakmai.itthon.hu/turizmus-magyarorszagon. Last viewd on July 28, 2017.

[35] Káptalantóti Község Önkormányzat Képviselö-testülete: Jegyzőkönyv Káptalantóti Község Önkormányzata Képviselö-testületének 2015. November 24-én 15.00 órakor megtartott soron következő nyilvános üléséröl.

file://C:/Users/User/Downloads/2015.11.24.\%20jegyz\%C5\%91k\%C3\%B6nyv\%20NY.pdf. Last viewd on December 31, 2017.

[36] Lantos, G. (2016). Egy kihagyhatatlan piac a Balatonnál. http://www.origo.hu/tafelspicc/nagyhasab/20160801-liliomkert-kaptalantoti-piac-kolbaszhazi-szorpok-regisegek.html. Last viewd on December 31, 2017.

[37] Molnár, Cs. (2015). Váratlan húzással menekült meg a balatoni kultpiac. Source: http://hvg.hu/gazdasag/20150505 kaptalantoti piac. Last viewd on December 31, 2017.

[38] Nezdei, Cs. (2018). A biotermékek lehetőségei a Balaton-térség fejlesztésében. (manuscript).

[39] Oláh, M. eds., (2013-2014). Balaton Kiemelt Üdülőkörzet Hosszú Távú Területfejlesztési Koncepciója 2014-2020. Helyzetelemzés. Balatoni Integrációs és Fejlesztési Ügynökség Nonprofit Kft, Balatonfüred - Siófok. 398 p. https://www.balatonregion.hu/aktualis-fejlesztesidokumentumok. Last viewed on September 19, 2018. 